UDC 577.112.083

\title{
Production, purification of the recombinant analog of Y-box-binding protein 1 and its interaction with poly(ADP-ribose), RNA, single- and double-stranded DNAs
}

\author{
E. E. Alemasova ${ }^{1}$, K. N. Naumenko ${ }^{1,2}$, P. E. Pestryakov ${ }^{1}$, O. I. Lavrik ${ }^{1,2}$ \\ ${ }^{1}$ Novosibirsk Institute of Chemical Biology and Fundamental Medicine, Siberian Branch of the Russian Academy of Sciences \\ 8, Akademika Lavrentieva Ave., Novosibirsk, Russian Federation, 630090 \\ ${ }^{2}$ Novosibirsk State University \\ 2, Pirogova Str., Novosibirsk, Russian Federation, 630090 \\ lisenok.istreb@gmail.com
}

\begin{abstract}
Aim. Production and purification of the recombinant histidine-tagged Y-box- binding protein 1 and study of its interaction with DNA, RNA and poly(ADP-ribose). Methods. Ligationindependent cloning, PCR, Sanger sequencing, protein chromatography, polyacrylamide gel electrophoresis, and electrophoresis mobility shift assay. Results. cDNA coding for the YB-1 protein has a previously undocumented two single nucleotide polymorphisms. The expression construct for production of the his-tagged YB-1 protein was designed to simplify the purification procedure and an appropriate protocol for protein purification was developed. Using electrophoresis mobility shift assay, we have shown that poly(ADP-ribose) competes with a double- and single-stranded DNA and RNA for binding to purified recombinant his-tagged YB-1. Conclusions. In the present work we developed and optimized the procedure of the recombinant YB-1 protein production and purification from bacterial cells. We found that poly(ADP-ribose) at high concentration is able to recruit YB-1 protein from the YB-1-DNA and YB-1-RNA complexes, suggesting a possible YB-1 involvement in DNA repair.
\end{abstract}

Ke y w or d s: YB-1, protein purification, poly(ADP-ribose) (PAR), DNA repair.

\section{Introduction}

Y-box-binding protein 1 (YB-1) is a multifunctional cellular factor increasingly considered as a potential universal regulator of different DNA repair systems [1]. Recent findings of our laboratory demonstrated YB-1 interplay with PARP1, the key regulatory protein of base excision repair pathway [2]. PARP1 binding to damaged DNA results in its activation followed by synthesis of nucleic acid-like polymer called poly(ADP-ribose) (PAR) using $\mathrm{NAD}+$ as a precursor. The functions of PAR in the regulation of DNA repair are amazingly numerous and include chromatin remodeling, recruitment of downstream repair enzymes and

(C) 2017 E. E. Alemasova et al.; Published by the Institute of Molecular Biology and Genetics, NAS of Ukraine on behalf of Biopolymers and Cell. This is an Open Access article distributed under the terms of the Creative Commons Attribution License (http://creativecommons.org/licenses/by/4.0/), which permits unrestricted reuse, distribution, and reproduction in any medium, provided the original work is properly cited 
modulation of interactions within the DNA repair complex [2]. PAR was also shown to effectively outcompete binding of histones to DNA [3] and proposed to assemble the noncanonical DNA repair proteins (usually RNAbinding [4]) at the damage site in a similar way [5]. However, it is not entirely clear if poly(ADP-ribose) may act as a preferable ligand for YB-1 in the presence of DNA and RNA as the YB-1 targets.

For further examination of YB-1 role in DNA repair it is necessary to provide sufficient amounts of the recombinant protein required for in vitro studies. The existing method of YB-1 purification is time-consuming since it includes three chromatographic and two dialysis stages [6]. Using histidine-tagged YB-1 is more advantageous since purification of a tagged protein can be performed during singlestep affinity chromatography. Moreover, obtained his-tagged YB-1 protein can be also used in pull-down assay for searching YB-1 protein partners in cell. Here we describe a producing strain for his-tagYB-1 expression in bacteria. Optimized purification procedure allowed us to obtain preparative quantities of the target protein. We also optimized the pro- tocol for preparation of poly(ADP-ribose) free from DNA cofactor used for the PARP1 activation and perform electrophoresis mobility shift assay (EMSA) to show that YB-1 binding to DNA, RNA or PAR may be regulated by PAR/ DNA or PAR/RNA ratio.

\section{Methods}

Construction of pLATE-51-his-tagYB-1 expression vector

The plasmid pET-3-1-YB-1 containing cDNA fragment of human YB-1 was a generous gift from Lev P. Ovchinnikov and Dmitry Kretov (Institute of Protein Research RAS, Moscow, Russian Federation). The plasmid was amplified in E.coli XL1Blue and isolated according to standard protocol. The presence of YB-1 cDNA insert was confirmed by PCR (with pET-U/pET-R primers, Table 1). The presence of mutations in YB-1 cDNA was analyzed by Sanger sequencing.

cDNA encoding YB-1 protein was cloned in pLATE-51 expression vector using aLICator LIC Cloning \& Expression System (Thermo Scientific, USA). YB-1 cDNA was amplified by PCR with specific primers plate51-forward

Table 1. Oligonucleotide sequences and designations

\begin{tabular}{|c|c|}
\hline pET-U & 5'-AGCCAACTCAGCTTCCTTTC-3' \\
\hline pET-R & 5'-ATAGGGAGACCACAACGGTT-3' \\
\hline $\begin{array}{l}\text { Plate-51 } \\
\text { Forward }\end{array}$ & 5'-GGAGATGGGAAGTCATTACTCAGCCCCGCCCTG-3' \\
\hline $\begin{array}{l}\text { Plate-51 } \\
\text { Reverse }\end{array}$ & 5'-GGTGATGATGATGACAAGAGCAGCGAGGCCGA-3' \\
\hline ssDNA & 5'-CGGTATCCACCAGGTCUGAGACAACGATGAAGCCCAAGCCAGATGAAATGTAGTC-3' \\
\hline dsDNA & $\begin{array}{l}\text { 5'-CGGTATCCACCAGGTCUGAGACAACGATGAAGCCCAAGCCAGATGAAATGTAGTC-3' } \\
\text { 3'-GCCATAGGTGGTCCAGACTCTGTTGCTACTTCGGGTTCGGTCTACTTTACATCAG-5' }\end{array}$ \\
\hline RNA & 5'-gggaga aaaaag aaagaa auguuc uucuuc uaagaa gaaaga aaagaa aaagaa aaaaga caaaga cacgaa ggaaga-3' \\
\hline
\end{tabular}


and plate51-reverse in GC-buffer (Biolabmix, Russian Federation) using pET3-I-YB-1 as a template, then purified by isopropanol precipitation and annealed with linearized pLATE-51 vector. E. coli DH5alpha competent cells were transformed by electroporation with resulting plasmid. The presence of pLATE51-YB-1 in transformant colonies, grown on medium containing ampicillin as selective antibiotic, was analyzed by colony PCR with specific primers plate51-forward and plate51-reverse.

\section{Purification of the recombinant his- tagYB-1 protein}

Expression of open reading frame encoding the his-tagYB-1 protein in E.coli BL21(DE3) was performed in the auto-induction system described by Studier [7]. The biomass ( $16 \mathrm{~g})$ was lysed by lysozyme treatment, sonicated and centrifuged to pellet cell debris. As the initial purification step we used metal affinity chromatography on a Ni-NTA resin. The column was equilibrated by Ni-A buffer (see Table 2 for details), then the supernatant was adjusted and washed with 10 column volumes
(CV) of Ni-A buffer. Protein elution from the column was performed by step gradient of imidazole from $20 \mathrm{mM}$ (0\% Ni-B buffer) to $250 \mathrm{mM}$ (50\% Ni-B). For additional purification we used ion exchange chromatography. After Mono S column (GE Healthcare, UK) equilibration by $25 \%$ Ion-B buffer, the sample was diluted in Ion-A (to $0.5 \mathrm{M} \mathrm{NaCl}$ ), adjusted, washed by $25 \%$ Ion-B and eluted by linear gradient of $\mathrm{KCl}$ from $0.5 \mathrm{M}(25 \%$ Ion-B) to $2 \mathrm{M}$ (100\% Ion-B). Gel filtration was employed as a final 'polishing' step. In this regard, the sample was concentrated by repeated chromatography on Mono S column using step gradient of $\mathrm{KCl}$ from $0.5 \mathrm{M}(25 \%$ Ion-B) to $1.5 \mathrm{M}$ (75\% Ion-B), adjusted on 16/600 Superdex 75 per grade column (GE Healthcare) equilibrated by GF-buffer and isocratically eluted. The resulting sample was concentrated by Vivaspin Turbo 15 (Sartorius, Germany) in Storage buffer (Table 2).

\section{PAR labeling in vitro}

Radioactively labelled (or unlabeled) PAR polymer was obtained as described previ-

\section{Table 2. Purification details}

\begin{tabular}{|c|c|c|}
\hline on step & Column & Buffers \\
\hline $\begin{array}{l}\text { 1. Metal affinity } \\
\text { chromatography }\end{array}$ & $\begin{array}{l}\text { Econo-Column }(\text { BioRad }) \\
\mathrm{L} \times \text { I.D. } 5 \mathrm{~cm} \times 10 \mathrm{~mm}+\mathrm{GE} \\
\text { HealthCare Ni-NTA resin }\end{array}$ & $\begin{array}{l}\text { Ni-A: } 20 \mathrm{mM} \text { Tris-HCl pH 8.0, } 1.5 \mathrm{M} \mathrm{NaCl}, 20 \mathrm{mM} \text { imidazole, } \\
10 \% \text { glycerol, } 0,1 \% \mathrm{NP}-40 \\
\text { Ni-B: } 20 \mathrm{mM} \text { Tris-HCl pH 8.0, } 1.5 \mathrm{M} \mathrm{NaCl}, 500 \mathrm{mM} \text { imidazole, } \\
10 \% \text { glycerol, } 0,1 \% \mathrm{NP}-40\end{array}$ \\
\hline $\begin{array}{l}\text { 2. Ion exchange } \\
\text { chromatography }\end{array}$ & $\begin{array}{l}\text { MonoS } 5 / 50 \mathrm{GL}(\mathrm{GE} \\
\text { HealthCare }), \mathrm{L} \times \text { I.D. } 5 \mathrm{~cm} \times \\
5 \mathrm{~mm}\end{array}$ & 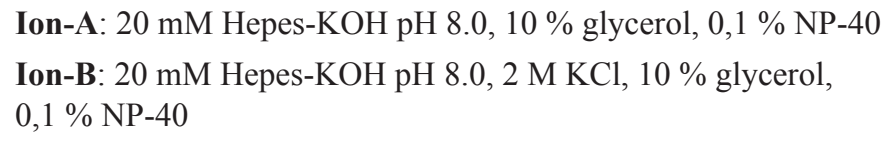 \\
\hline 3. Gel filtration & $\begin{array}{l}\text { 16/600 Superdex } 75 \mathrm{pg}(\mathrm{GE} \\
\text { HealthCare }), \mathrm{L} \times \text { I.D. } 60 \mathrm{~cm} \times \\
16 \mathrm{~mm}\end{array}$ & GF-buffer: $20 \mathrm{mM}$ Hepes-KOH pH 8.0, $1 \mathrm{M} \mathrm{KCl}$ \\
\hline $\begin{array}{l}\text { 4. His-tagYB-1 } \\
\text { concentration }\end{array}$ & $\begin{array}{l}\text { Vivaspin Turbo } 15 \text { (Sartorius) } \\
10 \mathrm{kDa} \text { MWCO }\end{array}$ & Storage buffer: $20 \mathrm{mM} \mathrm{KH}_{2} \mathrm{PO}_{4}, 0.5 \mathrm{M} \mathrm{KCl}, 20 \%$ glycerol \\
\hline
\end{tabular}


ously [9] with minor modifications. Briefly, DNA cofactor was removed by benzonase treatment and PAR was isolated from resulting sample by phenol:chloroform:isoamyl alcohol (25:24:1) extraction. PAR was additionally purified by ethanol precipitation and dissolved in $1 \mathrm{x}$ reaction buffer $(\mathrm{RB})(50 \mathrm{mM}$ Tris- $\mathrm{HCl} \mathrm{pH}$ 8.0, $40 \mathrm{mM} \mathrm{NaCl}, 8 \mathrm{mM} \mathrm{MgCl}{ }_{2}$, $1 \mathrm{mM}$ DTT) to the final concentration $1 \mathrm{~A}_{260}$ units/ml.

\section{His-tagYB-1 interaction with PAR, DNA and $R N A$}

To study PAR ability to compete with DNA for YB-1 binding, we used unlabeled PAR and radioactively labeled DNA. Reaction mixtures contained 1x RB, $400 \mathrm{nM}$ his-tagYB-1, $50 \mathrm{nM}$ ssDNA or dsDNA, and 0-8 $\mu$ l of PAR. To study DNA and RNA ability to compete with PAR for YB-1 binding, we used radioactively labeled PAR and unlabeled DNA (or RNA). ssRNA used in this study was kindly provided by Dmitriy Sharifulin (ICBFM SB RAS, Novosibirsk, Russia). Reaction mixtures contained 1x RB, $400 \mathrm{nM}$ his-tag YB-1, $1 \mu \mathrm{l}$ of PAR and $0-10 \mu \mathrm{M}$ DNA or RNA. His-tagYB-1 binding to DNA and PAR was performed for 5 min at $37{ }^{\circ}$ C. Samples were supplemented by loading buffer $(20 \mathrm{mM}$ Tris- $\mathrm{HCl} \mathrm{pH} 8.0$, $10 \%$ glycerol, $0.025 \%$ bromphenol blue) and analyzed by electrophoresis mobility shift assay at $10 \mathrm{~V} / \mathrm{cm}$ (PAAG contained $7 \%$ acrylamide, $0.09 \%$ bis-acrylamide, $0.5 x$ TBE buffer). Positions of YB-1-DNA or YB-1-PAR complexes were visualized by phosphorimaging with Typhoon FLA 7000 (GE Healthcare).

\section{Results and Discussion}

The YB-1 cDNA primary structure derived from Sanger sequencing was compared with the reference sequence of YBX1 gene coding for the YB-1 protein (NM_001082785.1). The data obtained testify that the YB-1 open reading frame contains two mutations: Pro-312 $\rightarrow$ Glu-312 (codon change $\mathrm{CCG} \rightarrow \mathrm{CAG}$ ) and Ser-313 $\rightarrow$ Arg-313 (codon change AGT $\rightarrow$ CGT) (Fig. 1). We suppose that these amino acid changes may represent previously undocumented YB-1 cDNA polymorphisms.

To obtain a target expression construct that contains YB-1 cDNA, N-terminally flanked by hexahistidine coding sequence, we used ligase independent cloning system (Supplementary, Fig. S1). The conditions of cell culture transformed by pLATE-51-YB-1 were optimized to achieve maximal yield of the target protein

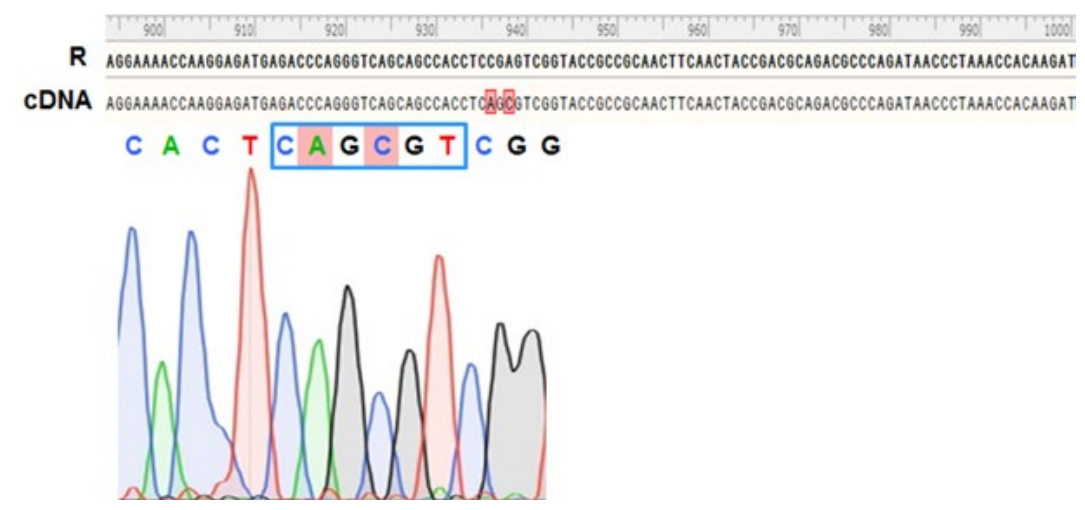

Fig. 1. Comparison of YB-1 cDNA sequence with reference sequence of YBX1 gene (R) and a fragment of chromatogram obtained after Sanger sequencing. Mutated codons are boxed, nucleotide changes are rubricated. 


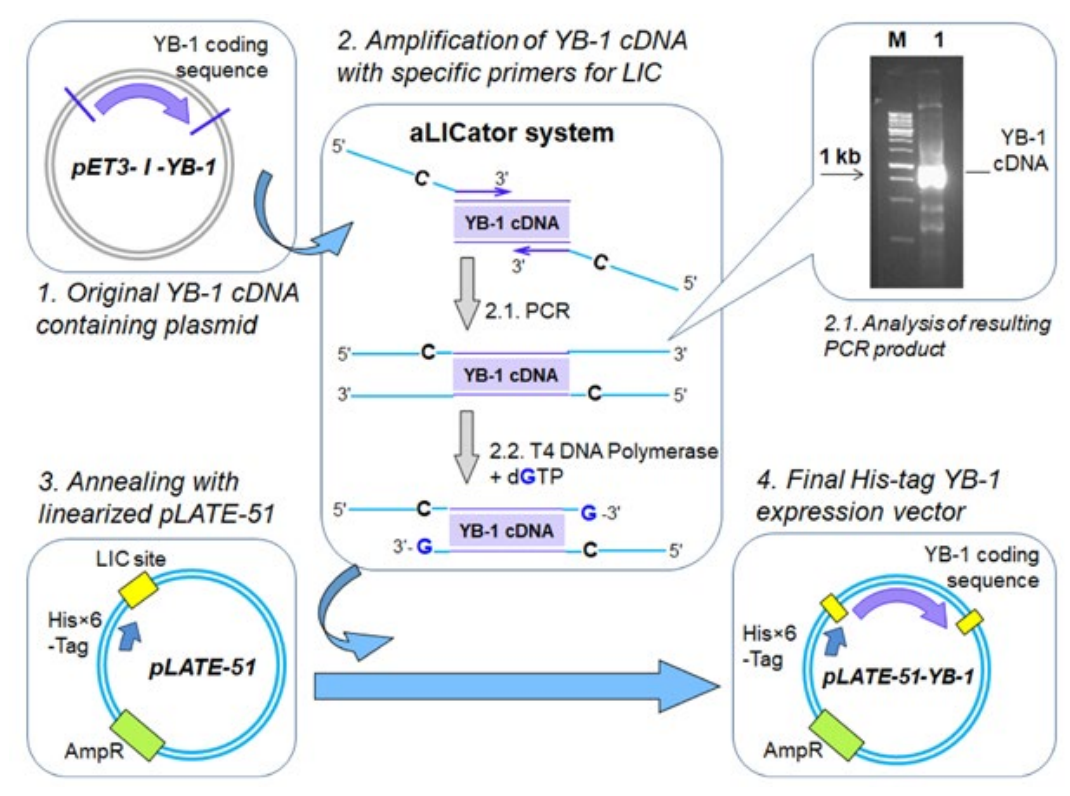

Supplementary, Figure S1. Construction of his-tagged YB-1 expression vector (scheme). in soluble form. Since a single-step metal affinity chromatography did not result in pure YB-1 preparation, two additional purification steps were performed (Fig. 2). Using this approach we obtained about $3 \mathrm{mg}$ of $\sim 90 \%$ purity his-tagYB-1 protein per 11 of bacterial culture. Thus, the yield of the target protein obtained by our purification protocol is three times higher compared to previously reported approach [6].

Previously, YB-1 was shown to bind poly(ADP-ribose) even in the presence of da-

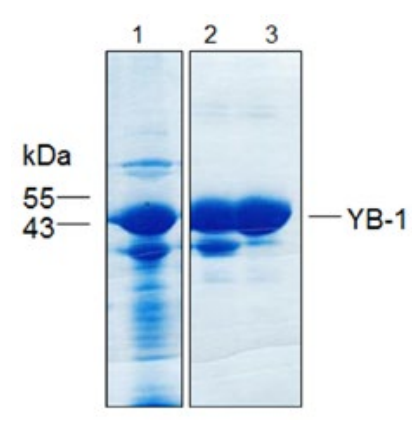

Fig. 2. Purification of histagged YB-1(Coomassie Brilliant Blue R-250 stained gel). Lane 1 - his-tagged YB-1protein after purification on Ni-NTA column; lane 2 - after Mono S column; lane 3 - after gel-filtration (final protein sample). maged DNA serving as a cofactor for the PARP1 activation [8]. However, the ability of PAR to compete with DNA for binding to YB-1 was not demonstrated yet. In the present study we employed an electrophoresis mobility shift assay to estimate the relative affinity of poly(ADP-ribose), DNA and RNA for histagYB-1 protein. First of all, we modified the protocol for PAR preparation [8] in order to eliminate DNA cofactor from the sample. Purified PAR was able to compete with singleand double-stranded DNA for binding to histagYB-1 (Fig. 3A). Reciprocally, ssDNA, dsDNA and RNA were shown to disrupt YB-1 complexes with PAR (Fig. 3B). Since PAR and nucleic acids can compete for YB-1, we propose that in the cellular context the YB-1 functions may be regulated by PAR/DNA and $\mathrm{PAR} / \mathrm{RNA}$ ratio. In this regard, an increase of PAR level induced by genotoxic stress may dynamically outcompete DNA- and RNAbinding of YB-1 and recruit this protein to 
A

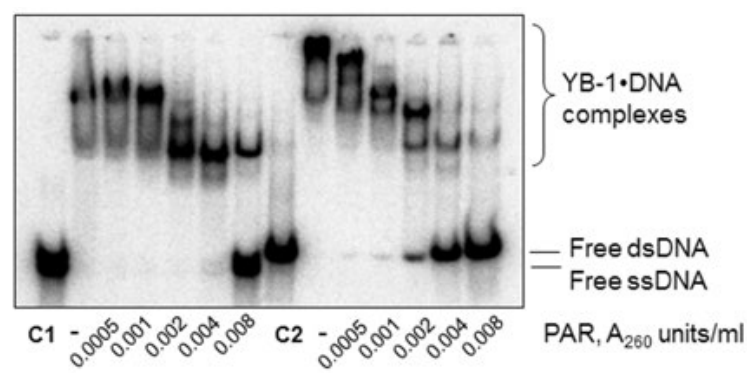

Fig. 3A. EMSA of YB-1 binding to radioactively labelled $50 \mathrm{nM}$ ssDNA (lanes 2-7) and $50 \mathrm{nM}$ dsDNA (lanes 9-14) in the presence of varying amounts of poly(ADP-ribose) $\left(0-0.008 \mathrm{~A}_{260}\right.$ units/ml). $\mathrm{C} 1$ - control for ssDNA, C2 control for dsDNA.

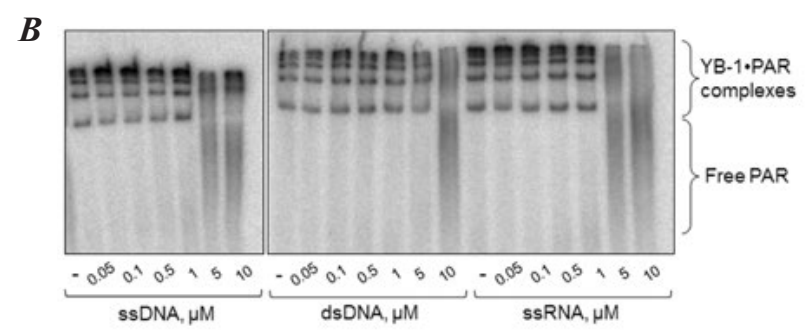

Fig. 3B. EMSA of YB-1 binding to radioactively labelled PAR $\left(0.001 \mathrm{~A}_{260}\right.$ units $\left./ \mathrm{ml}\right)$ in the presence of ssDNA, dsDNA and RNA $(0-10 \mu \mathrm{M})$.

DNA damage sites. Such mechanism might be similar to that proposed for RNA-binding proteins [5].

\section{Conclusions}

In the present work we developed a simple and efficient technique for the production and purification of histidine-tagged recombinant analog of YB-1 protein from bacterial cells. We found that poly(ADP-ribose) is able to compete with DNA and RNA for binding to YB-1 protein. We propose that high PAR concentration at the sites of genomic lesions may induce transient YB-1 relocalization from its complexes with nucleic acids to DNA damage sites. PAR-mediated recruitment of YB-1 to
DNA repair foci provides a basis for YB-1 involvement in the DNA repair process.

\section{Acknowledgements}

This work was supported by RFBR grant 1654-76010; GDRI program; Russian Ministry of Science and Education under 5-100 Excellence Program; Russian State funded budget project (VI.57.1.2, 0309-2016-0001); and educational fellowship from President of Russian Federation to young scientists and $\mathrm{PhD}$ students to AEE.

\section{REFERENCES}

1. Lyabin DN, Eliseeva IA, Ovchinnikov LP. YB-1 protein: functions and regulation. Wiley Interdiscip Rev RNA. 2014; 5(1): 95-110.

2. D'Amours D, Desnoyers $S$, D'Silva I, Poirier GG. Poly(ADP-ribosyl)ation reactions in the regulation of nuclear functions. Biochem J. 1999; 342(Pt 2): 249-68.

3. Muthurajan UM, Hepler MR, Hieb AR, Clark NJ, Kramer M, Yao T, Luger K. Automodification switches PARP-1 function from chromatin architectural protein to histone chaperone. Proc Natl Acad Sci U S A. 2014; 111(35): 12752-57.

4. Rulten SL, Rotheray A, Green RL, Grundy GJ, Moore DA, Gómez-Herreros F, Hafezparast $M$, Caldecott KW. PARP-1 dependent recruitment of the amyotrophic lateral sclerosis-associated protein FUS/TLS to sites of oxidative DNA damage. $\mathrm{Nu}$ cleic Acids Res. 2014; 42(1): 307-14.

5. Teloni F, Altmeyer M. Readers of poly(ADP-ribose): designed to be fit for purpose. Nucleic Acids Res. 2016; 44(3): 993-1006.

6. Kretov DA, Curmi PA, Hamon L, Abrakhi S, Desforges B, Ovchinnikov LP, Pastré D. mRNA and DNA selection via protein multimerization: $\mathrm{YB}-1$ as a case study. Nucleic Acids Res. 2015; 43(19): 9457-73.

7. Studier FW. Stable expression clones and auto-induction for protein production in E. coli. Methods Mol Biol. 2014; 1091: 17-32. 
8. Alemasova EE, Moor NA, Naumenko KN, Kutuzov MM, Sukhanova MV, Pestryakov PE, Lavrik OI. Y-box-binding protein 1 as a non-canonical factor of base excision repair. Biochim Biophys Acta. 2016; 1864(12): 1631-40.

\section{Отримання рекомбінантного аналога Y-бокс- зв'язуючого білка 1 і його взаємодію з полі (АДФ- рибозою), РНК, одно- і дволанцюговою ДНК}

Е. Е. Алемасова, К. Н. Науменко,

П. Е. Пестряков, О. І. Лаврик

Мета. Отримання рекомбінантного гістидин-міченого Y-бокс-зв'язуючий білрк 1 і дослідження його взаємодії з ДНК, РНК та полі (АДФ-рибозою). Методи. Безлігазне клонування, ПЛР, секвенування по Сенгеру, хроматографія, електрофорез в поліакриламідному гелі та метод затримки в гелі. Результати. кДНК ҮВ-1 містить дві раніше недокументовані поодинокі нуклеотидні заміни. Сконструйовано вектор для експресії гистидин-міченого білка YВ-1 і розроблена відповідна методика очищення білка. Методом затримки в гелі показано, що полі (АДФ-рибоза) конкурує з одно- і дволанцюговою ДНК, а також РНК, за зв>язування рекомбінантного гістидин-міченого білка ҮВ-1. Висновки. У цій роботі ми розробили та оптимізували процедуру отримання рекомбінантного білка YВ-1 з бактеріальних клітин. Ми встановили, що полі (АДФрибоза) у високій концентрації здатна витісняти білок YB-1 з його комплексів з ДНК і РНК, що вказує на можливість участі ҮВ-1 в репарації ДНК.

К л юч о в і с л о в а: YB-1, отримання рекомбінантного білка, поли (АДФ-рибоза) (PAR), репарація ДНК
Получение рекомбинантного аналога Ү-бокссвязывающего белка 1 и его взаимодействие с поли(АДФ-рибозой), РНК, однои двухцепочечной ДНК

Е. Э. Алемасова, К. Н. Науменко, П. Е. Пестряков, О. И. Лаврик

Цель. Получение рекомбинантного гистидин-меченого Ү-бокс-связывающего белка 1 и исследование его взаимодействий с ДНК, РНК и поли(АДФ-рибозой). Методы. Безлигазное клонирование, ПЦР, секвенирование по Сэнгеру, хроматография, электрофорез в полиакриламидном геле и метод задержки в геле. Результаты. кДНК ҮВ-1 содержит две ранее недокументированные одиночные нуклеотидные замены. Сконструирован вектор для экспрессии гистидин-меченого белка YB-1 и разработана соответствующая методика очистки белка. Методом задержки в геле показано, что поли(АДФ-рибоза) конкурирует с однои двухцепочечными ДНК, а также РНК, за связывание рекомбинантного гистидин-меченого белка YВ-1. Выводы. В настоящей работе мы разработали и оптимизировали процедуру получения рекомбинантного белка YВ-1 из бактериальных клеток. Мы установили, что поли(АДФ-рибоза) в высокой концентрации способна вытеснять белок ҮВ-1 из его комплексов с ДНК и РНК, что указывает на возможность участия YВ-1 в репарации ДНК.

К л ю че в ы е с л о в а: YB-1, получение рекомбинантного белка, поли(АДФ-рибоза) (PAR), репарация ДНК

Received 14.03.2017 